\title{
Serological survey of leptospirosis, brucellosis, and lentivirus in herds of small ruminants in Recôncavo Baiano, Bahia, Brazil
}

\author{
Inquérito sorológico de leptospirose, brucelose e lentiviroses em rebanhos \\ de pequenos ruminantes no Recôncavo Baiano, Bahia, Brasil
}

\author{
Rodrigo Rezende Mires de Carvalho; Lucas Nogueira Paz ${ }^{1}$; Carla Silva Dias ${ }^{1}$; Giselle Almeida Nocera²; \\ Augusto José Pereira de Mesquita ${ }^{3}$; Melissa Hanzen Pinna ${ }^{4}$ (D)
}

\author{
${ }^{1}$ Universidade Federal da Bahia, Programa de Pós-graduação em Ciência Animal nos Trópicos, Salvador - BA, Brazil \\ ${ }^{2}$ Instituto de Tecnologia do Paraná, Diretoria de Produção, Curitiba - PR, Brazil \\ ${ }^{3}$ Agência de Defesa Agropecuária da Bahia, Laboratório de Defesa e Saúde Animal, Salvador - BA, Brazil \\ ${ }^{4}$ Universidade Federal da Bahia, Departamento de Medicina Veterinária Preventiva e Produção Animal, Laboratório de Bacterioses, Salvador \\ - BA, Brazil
}

\begin{abstract}
A serological survey was carried out to assess the frequency of leptospirosis, small ruminants lentivirus (SRLV), and brucellosis in small ruminant herds in the Recôncavo Baiano, State of Bahia, Brazil, from February to December 2017. In four goat herds, 125 animals were tested for SRLV and leptospirosis, while in five sheep herds, 378 animals were tested for leptospirosis, brucellosis, and SRLV. Regarding leptospirosis, MAT detected $80 \%$ of goats and $15.34 \%$ of sheep seroreactive. Reactivity was most frequent to serogroups Autumnalis and Grippotyphosa in goats and sheep, respectively. Regarding SRLV, $8.8 \%$ of goats and $0.79 \%$ of sheep were reactive. Search for anti-B. ovis antibodies revealed $0.52 \%$ reactivity. In sheep, three animals showed simultaneous seroreactivity for SRLV and leptospirosis, while one animal had a serological response for brucellosis and leptospirosis. In goats, simultaneous seroreactivity for SRLV and leptospirosis was observed in only one animal. Leptospirosis was the most frequent of the three infectious diseases in investigated herds.
\end{abstract}

Keywords: Diagnosis. Reproductive changes. Leptospira spp. Caprine arthritis-encephalitis. Maedi-Visna. Brucella ovis.

\section{RESUMO}

Foi realizado um inquérito sorológico para avaliar a frequência de ocorrência de leptospirose, lentiviroses de pequenos ruminantes (LVPR) e brucelose em rebanhos de pequenos ruminantes no Recôncavo Baiano, estado da Bahia, Brasil, no período de fevereiro a dezembro de 2017. Em quatro rebanhos de caprinos, foram testados 125 animais para LVPR e leptospirose, enquanto em cinco rebanhos de ovinos, foram testados 378 animais para leptospirose, brucelose e LVPR. Em relação à leptospirose, $80 \%$ das cabras e $15,34 \%$ das ovelhas foram sororreativas. Os sorogrupos de Leptospira spp. predominantes foram Autumnalis e Grippotyphosa para caprinos e ovinos, respectivamente. Em relação as LVPR, $8,8 \%$ dos caprinos e $0,79 \%$ dos ovinos foram reativos. Adicionalmente, a pesquisa de anticorpos Anti-B. ovis revelou $0,52 \%$ de ovinos reativos. Em ovinos, três animais apresentaram sororreatividade simultânea para LVPR e leptospirose, enquanto um animal teve resposta sorológica para brucelose e leptospirose. Em caprinos, sororreatividade simultânea para LVPR e leptospirose foi observada em apenas um animal. A leptospirose foi a doença infecciosa mais frequente nos rebanhos investigados.

Palavras-chave: Diagnóstico. Alterações reprodutivas. Leptospira spp. Artrite encefalite caprina. Maedi-Visna. Brucella ovis. 
Correspondence to:

Melissa Hanzen Pinna

Universidade Federal da Bahia, Departamento de Medicina

Veterinária Preventiva e Produção Animal

Av. Adhemar de Barros, 500, Ondina

CEP: 40170-110, Salvador - Bahia, Brazil

E-mail: melissahp@ufba.br

Received: December 22, 2020

Approved: May 20, 2021

How to cite: Carvalho RRM, Paz LN, Dias CS, Nocera GA, Mesquita AJP, Pinna MH. Serological survey of leptospirosis, brucellosis, and lentivirus in herds of small ruminants in Recôncavo Baiano, Bahia, Brazil. Braz J Vet Res Anim Sci. 2021;58:e180290. https://doi.org/10.11606/ issn.1678-4456.bjvras.2021.180290

\section{Introduction}

Animal diseases that cross the species barrier cause high rates of death worldwide, heavily impacting low- and middle-income countries that practice small ruminant breeding (Torres-Velez et al., 2019). It is estimated that over $20 \%$ of animal production worldwide is hampered by infectious diseases, causing large economic losses (World Organisation for Animal Health, 2019). In Brazil, the annual production of goat and sheep meat was estimated at 172 thousand tons (US $\$ 153$ million- $-0.02 \%$ of GDP) and 22 thousand tons (US $\$ 6$ million- $-0.0008 \%$ of GDP) for goat milk (Instituto Brasileiro de Geografia e Estatística, 2017). Northeast is the region with the highest growth in this sector, with 7.6 million goats and 9 million sheep (Instituto Brasileiro de Geografia e Estatística, 2017). The state of Bahia concentrates the largest goat (2.960.443) and sheep (3.763.732) numbers, highlighting the importance of small ruminant breeding as a socioeconomic activity for the local scenario (Instituto Brasileiro de Geografia e Estatística, 2017; Magalhães et al., 2018). Additionally, this activity poses one of the main sources of food and income for producers (Ribeiro \& de Alencar, 2018).

The most-reported infectious diseases in goats and sheep are brucellosis, caprine arthritis-encephalitis (CAE), maedi-visna (MV), and leptospirosis, the latter was the most impactful in studies performed in goats and sheep, from April to November 2010 in Rio de Janeiro (Martins et al., 2012) and sheep of Minas Gerais, in 2007 (Dorneles et al., 2020). In Paraíba, search for anti-B. ovis antibodies in sheep revealed seroreactivity in the herds investigated (Santos et al., 2013). CAE (Lima et al., 2013) and MV (Martinez et al., 2011) were also reported in small ruminants in the micro- region of Juazeiro, in the state of Bahia. Leptospirosis is a zoonotic disease caused by pathogenic leptospires, in which humans are occasional hosts of an epidemiological cycle involving wild and domestic animals (Costa et al., 2015). Most infected livestock present the chronic form of leptospirosis with impaired fertility, abortion, stillbirth, and decreased milk and meat production with consequent extensive economic losses (Ellis, 2015).

Brucella ovis is the causative agent of a sexually transmitted infectious disease in domestic sheep. It is characterized by genital lesions and epididymitis in rams, placentitis, and abortions (rare) in ewes, and neonatal mortality in lambs (Elderbrook et al., 2019). Infected rams are responsible for introducing the disease into a herd. Brucellosis has already been described as one of the main causes of reproductive impairment and economic losses (Dorneles et al., 2020).

Small ruminants are also commonly infected by lentiviruses, which belong to the Retrovíridae family, genus Lentivirus, represented by two phylogenetic groups whose prototypes are the virus of Maedi-Visna (MV) and caprine arthritis-encephalitis (CAE) (Junkuszew et al., 2016). The primary clinical outcomes of lentivirus are arthritic, mammary, neurological, and pulmonary manifestations, the latter more frequently observed in sheep (World Organisation for Animal Health, 2018).

Considering the growth of breeding activities and the importance of epidemiologic data about infectious diseases in small ruminants, the objective of the study was to assess the occurrence of leptospirosis, SRLV, and brucellosis in sheep and goat to determine which infectious disease had the highest frequency in the Recôncavo Baiano, Northeastern of Brazil.

\section{Materials and Methods}

\section{Number of samples and laboratory test}

The study was conducted in different herds recruited as convenience samples located in the region of the Recôncavo, in the state of Bahia, between February and December 2017. The animals included in this study belonged to five distinct herds. Four herds were composed of both species in a total of 290 sheeps and 125 goats, whilst one herd consisted of 88 sheep. The animals were between 10 months and five years of age. The farms were under semi-intensive (2/5) and intensive (3/5) management systems. The herds were characterized by intense acquisition and transit of animals. The production was focused on animals of the Boer breed for meat production and dairy goat herds of the Saanen and 
Anglo-Nubiana breeds. The sheep herds sampled were of the Santa Inês breed with meat production aptitude.

Sera from 125 goats were tested for leptospirosis and SRLV, while sera from 378 sheep were tested for leptospirosis, B. ovis, and SRLV. For the detection of anti-Leptospira spp. antibodies, microscopic agglutination test (MAT) was performed, as recommended (World Organisation for Animal Health, 2018). The MAT panel was composed of 24 serovars representing 21 serogroups maintained in liquid medium (EMJH) through subculture (at $28-30^{\circ} \mathrm{C}$ ) in the collection of the Bacterial Laboratory of the Federal University of Bahia (LABAC-UFBA) (Table 1). Sera with titers $\geq 100$ were considered reactive and endpoint titers were determined starting from an initial dilution of 1:100.

For the detection of anti-Brucella ovis antibodies, the Agar Gel Immunodiffusion method (AGID) was performed, using a commercial kit (TECPAR, Curitiba, PR, Brazil). Serological diagnosis for both lentiviruses (CAE and $\mathrm{MV}$ ) was performed using AGID, with a commercial kit (BIOVETECH, Recife, PE, Brazil). The commercial test of AGID does not distinguish infection between CAE and MV. Therefore, we inferred the diagnosis as SRLV seroreactive animals. All procedures were performed according to the manufacturer's recommendations.

\section{Statistical analysis}

Seropositivity of each disease was expressed based on descriptive analysis, using absolute and relative distributions. The confidence interval (CI) of $95 \%$ with an acceptable error of $5 \%$ was considered significant. The proportion CI was analyzed using Epi InfoTM 7.2.3.1.

\section{Results}

Of the 125 goats evaluated for leptospirosis, 100 (80\%) were seroreactive (Table 2). Autumnalis (37\%), followed by Grippotyphosa $(28 \%)$, and Sejroe $(23 \%)$ were the most frequent serogroups. Titers of 100 were predominant $(54 \%, 54 / 100)$, followed by $200(41 \%, 41 / 100)$ (Table 3$)$. Of the 378 sheep samples tested, 58 (15.34\%) were reactive (Table 2). Serogroups Grippotyphosa (39.66\%) and Tarassovi (27.58\%) were predominant. In sheep, titers of 100 were the most frequent $(75.86 \%, 44 / 58)$ (Table 4 ).

The serological survey for anti-SRLV antibodies showed $8.8 \%$ and $0.79 \%$ of seroreactivity for goats and sheep, respectively (Table 2). Of the 378 samples tested for the presence of anti- B. ovis antibodies, only two $(0.52 \%)$ were reactive (Table 2).

In sheep, three animals were simultaneously seroreactive for SRLV and leptospirosis (all with titers of 100 for Grippotyphosa), while one animal demonstrated concomitant serological response for brucellosis and leptospirosis (titer of

Table 1 - Serovars used as antigen to perform the microscopic agglutination test (MAT)

\begin{tabular}{|c|c|c|c|}
\hline Specie & Serogroup & Serovar & Strain \\
\hline L. interrogans & Australis & Bratislava & Jez Bratislava \\
\hline L. interrogans & Autumnalis & Autumnalis & Akiyami A \\
\hline L. borgpetersenii & Ballum & Castellonis & Castellon 3 \\
\hline L. interrogans & Bataviae & Bataviae & Van Tienen \\
\hline L. interrogans & Canicola & Canicola & Hond Utrecht IV \\
\hline L. weilii & Celledoni & Celledoni & Celledoni \\
\hline L. kirschneri & Cynopteri & Cynopteri & $3522 \mathrm{C}$ \\
\hline L. interrogans & Djasiman & Djasiman & Djasiman \\
\hline L. kirschneri & Grippotyphosa & Grippotyphosa & Moskva V \\
\hline L. interrogans & Hebdomadis & Hebdomadis & Hebdomadis \\
\hline L. interrogans & Icterohaemorrhagiae & Copenhageni & M20 \\
\hline L. interrogans & Icterohaemorrhagiae & Copenhageni & L1 130 \\
\hline L. interrogans & Icterohaemorrhagiae & Icterohaemorrhagiae & RGA \\
\hline L. borgpetersenii & Javanica & Javanica & Poi \\
\hline L. noguchii & Louisiana & Louisiana & LUC1945 \\
\hline L. borgpetersenii & Mini & ND & $2008 / 01925$ \\
\hline L. noguchii & Panama & Panama & CZ $214 \mathrm{~K}$ \\
\hline L. interrogans & Pomona & Pomona & Pomona \\
\hline L. interrogans & Pyrogenes & Pyrogenes & Salinem \\
\hline L. interrogans & Sejroe & Hardjo & Hardjoprajitino \\
\hline L. borgpetersenii & Sejroë & Sejroë & M 84 \\
\hline L. biflexa & Semaranga & Patoc & Patoc 1 \\
\hline L. santarosai & Shermani & Shermani & $1342 \mathrm{~K}$ \\
\hline L. borgpetersenii & Tarassovi & Tarassovi & Mitis Johnson \\
\hline
\end{tabular}


Table 2 - Serological survey for anti-Leptospira spp., Anti- SRLV, and anti-B. ovis antibodies in small ruminants in the Recôncavo region, Bahia, Brazil, from February to December 2017

\begin{tabular}{cccc}
\hline Species & Disease & No. samples tested & Reactive (\%) \\
\hline Goats & Leptospirosis & 125 & $100^{\mathrm{a}}(80.0 \%)$ \\
& SRLV & 125 & $11(8.8 \%)$ \\
Sheep & Leptospirosis & 378 & $58^{\mathrm{a}}(15.34 \%)$ \\
& B. ovis & 378 & $2(0.52 \%)$ \\
& SRLV & 378 & $3(0.79 \%)$ \\
\hline
\end{tabular}

${ }^{a}$ Significant difference with other infections

$\mathrm{SRLV}=$ small ruminants lentiviruses

Table 3 - Distribution of serogroups reactive by microscopic agglutination test (MAT) performed seroreactive goats from Recôncavo, in the state of Bahia, Brazil, from February to December 2017

\begin{tabular}{|c|c|c|c|c|c|}
\hline \multirow{2}{*}{ Serogroup } & \multicolumn{4}{|c|}{ Titers } & \multirow{2}{*}{ Total N (\%) } \\
\hline & 100 & 200 & 400 & $\geq 800$ & \\
\hline Pyrogenes & 0 & 0 & 0 & 1 & $1(1.0)$ \\
\hline Hebdomadis & 4 & 0 & 0 & 0 & $4(4.0)$ \\
\hline Grippotyphosa & 24 & 3 & 1 & 0 & $28(28.0)$ \\
\hline Sejroe & 23 & 0 & 0 & 0 & $23(23.0)$ \\
\hline Australis & 0 & 1 & 0 & 0 & $1(1.0)$ \\
\hline Celledoni & 0 & 1 & 0 & 0 & $1(1.0)$ \\
\hline Tarassovi & 2 & 0 & 2 & 0 & $4(4.0)$ \\
\hline Autumnalis & 0 & 36 & 1 & 0 & 37 (37.0) \\
\hline Sejroe & 1 & 0 & 0 & 0 & $1(1.0)$ \\
\hline Total & 54 & 41 & 4 & 1 & $100(100.0)$ \\
\hline
\end{tabular}

Table 4 - Distribution of serogroups reactive in microscopic agglutination test (MAT) performed seroreactive sheep from Recôncavo, in the state of Bahia, Brazil, from February to December 2017

\begin{tabular}{|c|c|c|c|c|c|}
\hline \multirow{2}{*}{ Serogroup } & \multicolumn{4}{|c|}{ Titers } & \multirow{2}{*}{ Total N (\%) } \\
\hline & 100 & 200 & 400 & $\geq 800$ & \\
\hline Pyrogenes & 0 & 1 & 1 & 0 & $2(3.45)$ \\
\hline Grippotyphosa & 21 & 1 & 1 & 0 & $23(39.66)$ \\
\hline Australis & 1 & 1 & 0 & 0 & $2(3.45)$ \\
\hline Celledoni & 4 & 1 & 0 & 0 & $5(8.62)$ \\
\hline Tarassovi & 15 & 1 & 0 & 0 & $16(27.58)$ \\
\hline Autumnalis & 0 & 4 & 1 & 0 & $5(8.62)$ \\
\hline Sejroe & 2 & 1 & 0 & 0 & $3(5.17)$ \\
\hline Shermani & 1 & 0 & 1 & 0 & $2(3.45)$ \\
\hline Total & 44 & 10 & 4 & 0 & $58(100.0)$ \\
\hline
\end{tabular}

400 for Autumnalis). In goats, simultaneous seroreactivity to SRLV and leptospirosis was observed in only one animal (titer of 200 for Autumnalis). It must be emphasized that leptospirosis was the common disease in all animals that presented simultaneous seroreactivity.

\section{Discussion}

Small ruminants can act as reservoir hosts for different infectious agents with relevant economic losses, representing a growing concern to public health (Dorjee et al., 2008;
Martins \& Lilenbaum, 2014). Here was demonstrated the exposure of the studied herds to Leptospira spp. through the high detection of anti-Leptospira spp. antibodies in goats and sheep. Additionally, it is inferred that leptospirosis is the main reproduction disease in small ruminants in the studied herds. Similar findings were observed in other studies performed in southeastern Brazil, in the state of Rio de Janeiro (Martins et al., 2012; Lilenbaum et al., 2007). This suggests possible sanitary management failures in the herds, denoting the importance of implementing diagnostic, prophylactic, and control measures in the region.

Other serological surveys in sheep and goats from Rio de Janeiro (Martins et al., 2012), Minas Gerais (Santos et al., 2012), and the semiarid region of the state of Paraíba (Higino et al., 2013) revealed the occurrence of reactions to serogroups Autumnalis, Grippotyphosa, Sejroe, Celledoni, and Tarassovi, corroborating our findings. In the present study reactions to serogroups Autumnalis and Grippotyphosa were the most frequent in goats and sheep, respectively, corroborating with other investigations carried out in the National Park of Serra das Confusões, state Piauí and rural areas of the state of Pernambuco (Santos et al., 2017), as well as the Sertão mesoregion of the state of Paraíba. All are located in northeastern Brazil (Silva et al., 2019).

In the herds studied, it was observed serological reactions to a variety of serogroups. Therefore, it is believed that contact with wild animals and rodents, as well as the presence of cattle on the properties, contributed to the occurrence of the disease since serological reactions have been evidenced for serovars usually maintained by more than one species (Araújo Neto et al., 2010; Soares et al., 2020). The serogroups Autumnalis and Grippotyphosa were previously isolated from wild animals, especially rodents found in rural areas, suggesting their role as reservoirs and possible transmitters of leptospirosis (Agudelo-Flórez et al., 2009). The occurrence of seroreactivity to these serogroups demonstrates the possibility of rodent participation in leptospiral transmission, emphasizing the need for control of synanthropic populations (Santos et al., 2017).

The occurrence of serological reactions to serovars Hardjo and Wolffi, representatives of the Sejroe serogroup, could be attributed to the close contact between sheep and cattle. The members of the Sejroe serogroup are maintained by cattle and usually transmitted from them to other species, mainly small ruminants (Adler \& De La Peña Moctezuma, 2010; Pinna et al., 2018). Studies suggest that small ruminants have been establishing the status of gradual adaptation to other serovars, including Hardjo, acting as carriers of leptospires and shedding the agent in the environment for long periods (Dorjee et al., 2008; Lilenbaum et al., 2009). 
The climatic conditions of the studied region may also contribute to the high prevalence of leptospirosis. Small ruminants located in tropical climates are almost three times more likely to be seroreactive than those from temperate ones (Lilenbaum et al., 2008). Although the present findings were similar to other studies conducted in Brazil, the leptospiral seroreactivity found in the examined herds was higher than those reported in other tropical countries: 4.7\% (sheep) and 7.9\% (goats) in Thailand (Suwancharoen et al., 2013), 5\% (sheep) and 3.3\% (goats) in Trinidad (Suepaul et al., 2011) and $8.47 \%$ (goats) in Tanzania (Assenga et al., 2015).

In tropical regions, the presence of larger herds and the high number of serovars isolated increase the chances of exposure to the agent. (Faine et al., 2000). Therefore, tropics pose as ideal scenarios for the maintenance and spread of leptospirosis: elevated rainfall rates together with a variety of wild, synanthropic, and domestic reservoirs may contribute to the continuous transmission of the bacteria (Pappas et al., 2008; Almeida et al., 2019). The occurrence of leptospirosis represents an important factor affecting herd performance. Consequently, milk and meat production tend to decrease, leading to important financial difficulties for farmers (Martins \& Lilenbaum, 2014).

SRLV and Brucella spp. infections cause debilitating illnesses with induced inflammatory pathology of several organs, leading to the progressive emaciation of the animal (Junkuszew et al., 2016; Larruskain \& Jugo, 2013). These agents mainly infect polymorphonuclear cells and monocytic-phagocytic lineage (Larruskain \& Jugo, 2013; Li et al., 2014). Therefore, it is known that the animals presenting concomitant diseases may have drawbacks in their humoral response, with a consequent predisposition to develop the most severe form of leptospirosis (Chen et al., 2020).

Studies report the occurrence of CAE and MV in various states of Brazil, with seroreactivity ranging from $0.29 \%$ to $17.6 \%$ (Bandeira et al., 2009; Sousa et al., 2019; Dorneles et al., 2020). The low seroreactivity to SRLV detected in the present study corroborates other studies performed in the northeastern region of Brazil. Lima et al., (2013) found $0.29 \%$ reactivity in goats from the Baixo Médio São Francisco region, Bahia. In the state of Pernambuco, $1.89 \%$ of goats' and $0.26 \%$ of sheep's samples were reactive (Melo et al., 2016). Regarding brucellosis, the presence of anti- $B$. ovis antibodies have a variable presentation in different states of the country, such as $7.5 \%$ in Paraíba (Alves et al., 2010), 6.1\% in Rio de Janeiro (Martins et al., 2012), and 24.04\% in Minas Gerais (Dorneles et al., 2020). The seroreactivity to brucellosis was extremely low in all herds studied, corroborating with other reports from Bahia
(Souza et al., 2012) and Rio de Janeiro (Lilenbaum et al., 2007). The occurrence of these diseases is of great concern in small ruminants due to the consequent decrease in milk and meat production, reduced fertility in rams, lower conception rates in ewes, abortion, and decreasing numbers of healthy lambs' birth (Elderbrook et al., 2019; Martins et al., 2012).

The variable frequency between distinct regions can be a consequence of different management systems, geographical location, demographic concentration, animal transit, host susceptibility, the interaction between species, and characteristics of the etiologic agent (Higino et al., 2013). The herds studied were characterized by intense acquisition and transit of animals. Therefore, the occurrence of these pathogens should be expected, since intensive management promotes higher contact between animals, favoring the spread and transmission of infectious agents (Junkuszew et al., 2016; Campos et al., 2017; Santos et al., 2017).

The lower seroreactivity for brucellosis and SRLV observed in this study demonstrates that control and sanity programs may reduce the occurrence of these diseases in the affected areas, corroborating the report of Martins et al. (2012). In contrast, leptospirosis is a neglected disease within the governmental health program. The high occurrence of leptospirosis has a relevant impact on public health since sheep may carry the bacteria in the kidneys for long periods (Almeida et al., 2019). This extended shedding via urine constitutes a zoonotic risk for handlers and owners. Therefore, to reduce exposure and infections by leptospires, more efforts towards health education, disease control, and inspection are needed.

The development of these activities is affected by the inefficient sanitary management practices for leptospirosis control. In small ruminant breeding negligence towards leptospirosis controls and detection increases the incidence of the disease, determining the low productivity of the sector (Campos et al., 2017; Salaberry et al., 2011). However, as observed in the present study and as reported in the herds studied by Martins et al. (2012), the frequency of CAE, MV and Brucellosis was reduced due to the implementation of animal health and control programs. The low seroreactivity for these diseases is an interesting finding and suggests advantages in the inclusion of leptospirosis within an official program, emphasizing the importance of implementation of sanitary management applied to the control and the prevention of infectious agents in small ruminant herds.

\section{Conclusion}

The serological investigation of leptospirosis, small ruminants lentivirus (SRLV), and brucellosis 
in small ruminants from herds of Recôncavo region Bahia State, Brazil showed that leptospirosis was the most frequent of them. It is proposed that the establishment of leptospirosis control programs with identification of infected animals, combined with treatment, prophylaxis, health management, and requirement of health status documents for animal transit may be applied for reducing the economic and productive losses in these herds.

\section{References}

Adler B, de la Peña Moctezuma A. Leptospira and leptospirosis. Vet Microbiol. 2010;140(3-4):287-96. http:// dx.doi.org/10.1016/j.vetmic.2009.03.012. PMid:19345023.

Agudelo-Flórez P, Londono AF, Quiroz VH, Ángel JC, Moreno N, Loaiza ET, Muñoz LF, Rodas JD. Prevalence of Leptospira spp. in urban rodents from a groceries trade center of Medellin, Colombia. Am J Trop Med Hyg. 2009;81(5):906-10. http:// dx.doi.org/10.4269/ajtmh.2009.09-0195. PMid:19861630.

Almeida DS, Paz LN, de Oliveira DS, Silva DN, Ristow P, Hamond C, Costa F, Portela RW, Estrela-Lima A, Pinna $\mathrm{MH}$. Investigation of chronic infection by Leptospira spp. in asymptomatic sheep slaughtered in slaughterhouse. PLoS One. 2019;14(5):e0217391. http://dx.doi.org/10.1371/ journal.pone.0217391. PMid:31120961.

Alves CJ, de Figueiredo SM, de Azevedo SS, Clementino IJ, Keid LB, Vasconcellos SA, de Sousa Américo Batista C, Rocha VC, Higino SS. Detection of Brucella ovis in ovine from Paraíba State, in the Northeast region of Brazil. Braz J Microbiol. 2010;41(2):365-7. http://dx.doi.org/10.1590/ S1517-83822010000200016. PMid:24031505.

Araújo-Neto JO, Alves CJ, Azevedo SS, Silva MLCR, Batista CDSA. Soroprevalência da leptospirose em caprinos da microrregião do Seridó Oriental, Estado do Rio Grande do Norte, Brasil, e pesquisa de fatores de risco. Braz J Vet Res Anim Sci. 2010;47(2):144-8. http://dx.doi.org/10.11606/ issn.1678-4456.bjvras.2010.26839.

Assenga JA, Matemba LE, Muller SK, Mhamphi GG, Kazwala RR. Predominant leptospiral serogroups circulating among humans, livestock and wildlife in Katavi-Rukwa ecosystem, Tanzania. PLoS Negl Trop Dis. 2015;9(3):e0003607. http:// dx.doi.org/10.1371/journal.pntd.0003607. PMid:25806825.

Bandeira DA, de Castro RS, Azevedo EO, de Souza Seixas Melo L, de Melo CB. Seroprevalence of caprine arthritis-

\section{Conflict of Interest}

The authors declare that they have no conflict of interest.

\section{Ethics Statement}

All the procedures involving animals were approved and followed the ethical standards for animal experimentation established by the Ethics Committee in the Use of Animals at the Federal University of Bahia (CEUA - EMEVZ/UFBA, process: 554/2013).

encephalitis virus in goats in the Cariri region, Paraiba state, Brazil. Vet J. 2009;180(3):399-401. http://dx.doi. org/10.1016/j.tvjl.2008.02.007. PMid:18675568.

Campos ÂP, Miranda DFH, Rodrigues HWS, da Silva Carneiro Lustosa M, Martins GHC, Mineiro ALBB, Castro V, Azevedo SS, de Sousa Silva SMM. Seroprevalence and risk factors for leptospirosis in cattle, sheep, and goats at consorted rearing from the State of Piauí, northeastern Brazil. Trop Anim Health Prod. 2017;49(5):899-907. http:// dx.doi.org/10.1007/s11250-017-1255-2. PMid:28357645.

Chen X, Xie X, Wu D, Zhang S, Zhang W, Cao Y. The pre-activated immune response induced by LPS protects host from leptospirosis. PLoS One. 2020;15(11):e0242742. https://doi.org/10.1371/journal.pone.0242742.

Costa F, Hagan JE, Calcagno J, Kane M, Torgerson P, Martinez-Silveira MS, Stein C, Abela-Ridder B, Ko AI. Global morbidity and mortality of leptospirosis: a systematic review. PLoS Negl Trop Dis. 2015;9(9):1-19.

Dorjee S, Heur C, Jackson R, West DM, Collins-Emerson JM, Midwinter AC, Ridler AL. Prevalence of pathogenic Leptospira spp. in sheep in a sheep-only abattoir in New Zealand. New Zeal Vet J. 2008;56(4):164-70.

Dorneles EMS, Guimarães AS, Gouveia AMG, Coura FM, Carmo FB, Pauletti RB, Azevedo V, Lilenbaum W, Vitor RWA, Pinheiro RR, Ferreira ACR, Dasso MG, Lage AP, Heinemann MB. Seroprevalence of Brucella ovis-epididymitis, smooth-Brucella, leptospirosis, toxoplasmosis, and MaediVisna in sheep slaughtered in Minas Gerais State, Brazil. Braz J Vet Res Anim Sci. 2020;57(2):164278-164278. http:// dx.doi.org/10.11606/issn.1678-4456.bjvras.2020.164278.

Elderbrook M, Schumaker B, Cornish T, Peck D, Sondgeroth K. Seroprevalence and risk factors of Brucella ovis in domestic 
sheep in Wyoming, USA. BMC Vet Res. 2019;15(1):246. http:// dx.doi.org/10.1186/s12917-019-1995-5. PMid:31307483.

Ellis WA. Animal leptospirosis. Curr Top Microbiol Immunol. 2015;387:99-137. http://dx.doi.org/10.1007/978-3-66245059-8_6. PMid:25388134.

Faine S, Adler B, Bolin C, Perolat P. Leptospira and leptospirosis. Melbourne: Australia MediSci; 2000.

Higino SSS, Santos FA, Costa DF, Santos CSAB, Silva MLCR, Alves CJ, Azevedo SS. Flock-level risk factors associated with leptospirosis in dairy goats in a semiarid region of Northeastern Brazil. Prev Vet Med. 2013;109(1-2):15861. http://dx.doi.org/10.1016/j.prevetmed.2012.09.005. PMid:23031326.

Instituto Brasileiro de Geografia e Estatística. Sistema IBGE de Recuperação Automática - SIDRA [Internet]. Rio de Janeiro: IBGE; 2017 [cited 2020 Dec 22]. Available from: from: www.sidra.ibge.gov.br.

Junkuszew A, Dudko P, Bojar W, Olech M, Osiński Z, Gruszecki TM, Kania MG, Kuźmak J, Czerski G. Risk factors associated with small ruminant lentivirus infection in eastern Poland sheep flocks. Prev Vet Med. 2016;127:449. http://dx.doi.org/10.1016/j.prevetmed.2016.03.011. PMid:27094139.

Larruskain A, Jugo BM. Retroviral infections in sheep and goats: small ruminant lentiviruses and host interaction. Viruses. 2013;5(8):2043-61. http://dx.doi.org/10.3390/ v5082043.

Li JY, Liu Y, Gao XX, Gao X, Cai H. TLR2 and TLR4 signaling pathways are required for recombinant Brucella abortus BCSP31-induced cytokine production, functional upregulation of mouse macrophages, and the Th1 immune response in vivo and in vitro. Cell Mol Immunol. 2014;11(5):477-94. http://dx.doi.org/10.1038/cmi.2014.28. PMid:24769793.

Lilenbaum W, de Souza GN, Ristow P, Moreira MC, Fráguas S, Cardoso VS, Oelemann WM. A serological study on Brucella abortus, caprine arthritis-encephalitis virus and Leptospira in dairy goats in Rio de Janeiro, Brazil. Vet J. 2007;173(2):408-12. http://dx.doi.org/10.1016/j. tvjl.2005.12.003. PMid:16455276.

Lilenbaum W, Varges R, Medeiros L, Cordeiro AG, Cavalcanti A, Souza GN, Richtzenhain L, Vasconcellos SA. Risk factors associated with leptospirosis in dairy goats under tropical conditions in Brazil. Res Vet Sci. 2008;84(1):14-7. http:// dx.doi.org/10.1016/j.rvsc.2007.03.011. PMid:17543359.
Lilenbaum W, Varges R, Ristow P, Cortez A, Souza SO, Richtzenhain JL, Vasconcellos AS. Identification of Leptospira spp. carriers among seroreactive goats and sheep by polymerase chain reaction. Res Vet Sci. 2009;87(1):16-9. http://dx.doi.org/10.1016/j.rvsc.2008.12.014. PMid:19232418.

Lima CCV, Costa JN, Souza TS, Martinez P, Costa AO No, Anunciação AVM, Almeida MGÁR, Araújo BR, Pinheiro $\mathrm{RR}$. Inquérito soroepidemiológico do lentivírus caprino e perfil das criações de caprinos na região do Baixo Médio São Francisco (BA). Arq Inst Biol. 2013;80(3):288-96. http:// dx.doi.org/10.1590/S1808-16572013000300005.

Magalhães KA, Martins EC, Holanda ZF Fo, Lucena CC. Pesquisa Pecuária Municipal 2017: efetivo dos rebanhos caprinos e ovinos. Sobral: Embrapa Caprinos e Ovinos; 2018. (Boletim do Centro de Inteligência e Mercado de Caprinos e Ovinos, No. 5).

Martinez PM, Costa JN, De Souza TS, De Lima CCV, Costa Neto AO, Pinheiro RR. Prevalência sorológica da Maedi-Visna em rebanhos ovinos damicrorregião de Juazeiro-Bahia por meio do teste de imunodifusão em gel de ágar. Ci Anim Bras. 2011;12(2):322-329. http://dx.doi. org/10.5216/cab.v12i2.4454.

Martins G, Lilenbaum W. Leptospirosis in sheep and goats under tropical conditions. Trop Anim Health Prod. 2014;46(1):11-7. http://dx.doi.org/10.1007/s11250-0130480-6.

Martins G, Penna B, Hamond C, Leite CR, Silva A, Ferreira A, Brandão F, Oliveira F, Lilenbaum W. Leptospirosis as the most frequent infectious disease impairing productivity in small ruminants in Rio de Janeiro, Brazil. Trop Anim Health Prod. 2012;44(4):773-7.http://dx.doi.org/10.1007/ s11250-011-9964-4. PMid:21898182.

Melo EX, Almeida EC, Mendonça KMN, Nascimento SA, Silva JCR, Marvulo MFV, Rizzo H, Castro RS. Seroprevalence small ruminant lentiviruses in the state of Pernambuco slaughterhouses, Brazil. Arq Inst Biol. 2016;83:e0462015. http://dx.doi.org/10.1590/1808-1657000462015.

Pappas G, Papadimitriou P, Siozopoulou V, Christou L, Akritidis N. The globalization of leptospirosis: worldwide incidence trends. Inter. Int J Infect Dis. 2008;12(4):351-7. http://dx.doi.org/10.1016/j.ijid.2007.09.011. PMid:18055245.

Pinna MH, Martins G, Loureiro AP, Lilenbaum W. Detection of bovine carriers of Leptospira by serological, bacteriological, and molecular tools. Trop Anim Health 
Prod. 2018;50(4):883-8. http://dx.doi.org/10.1007/s11250018-1512-z. PMid:29349716.

Ribeiro KÁ, de Alencar CMM. Desenvolvimento territorial e a cadeia produtiva da caprinovinocultura no semiárido baiano: o caso do município de Juazeiro-BA. Rev Bras Estud Urbanos Reg. 2018;4(1):144-79. http://dx.doi.org/10.18224/ baru.v4i1.6571.

Salaberry SRS, Castro V, Nassar AFC, Castro JR, Guimarães EC, Lima-Ribeiro AMC. Seroprevalence and risk factors of antibodies against Leptospira spp. in ovines from Uberlândia municipality, Minas Gerais state, Brazil. Braz J Microbiol. 2011;42(4):1427-33. http://dx.doi.org/10.1590/ S1517-83822011000400026. PMid:24031773.

Santos FA, Higino SS, Azevedo SS, Costa DF, Farias AE, Alves FAL, Paulin LM, Alves CJ. Caracterização epidemiológica e fatores de risco associados à infecção por Brucella ovis em ovinos deslanados do semiárido paraibano. Pesq Vet Bras. 2013;33(4):459-63. http://dx.doi.org/10.1590/S0100736X2013000400008.

Santos LF, Guimarães MF, Souza GO, Silva IWG, Santos JR, Azevedo SS, Labruna MB, Heinemann MB, Horta MC. Seroepidemiological survey on Leptospira spp. infection in wild and domestic mammals in two distinct areas of the semi-arid region of northeastern Brazil. Trop Anim Health Prod. 2017;49(8):1715-22. http://dx.doi.org/10.1007/ s11250-017-1382-9. PMid:28861677.

Santos PJ, Lima-Ribeiro AMC, Oliveira PR, Santos MP, Ferreira Jr A, Medeiros AA, Tavares TCF. Seroprevalence and risk factors for Leptospirosis in goats in Uberlândia, Minas Gerais, Brazil. Trop Anim Health Prod. 2012;44(1):101-6. http://dx.doi.org/10.1007/s11250-011-9894-1. PMid:21647773.

Silva AF, Farias PJA, Silva MLCR, Araújo JP Jr, Malossi CD, Ullmann LS, Costa DF, Higino SSS, Azevedo SS, Alves CJ. High frequency of genital carriers of Leptospira sp. in sheep slaughtered in the semi-arid region of northeastern Brazil. Trop Anim Health Prod. 2019;51(1):43-7. http:// dx. doi:10.1007/s11250-018-1657-9.

Soares PM, Gomes DO, Macedo FP, Soares MM, Lemes KR, Jaeger LH, Lilenbaum W, Lima AMC. Serological and molecular characterization of Leptospira kirschneri serogroup Grippotyphosa isolated from bovine in Brazil.
Microb Pathog. 2020;138:103803. http://dx.doi.org/10.1016/j. micpath.2019.103803. PMid:31626918.

Sousa MM, Andrioli A, Pinheiro RR, Alves FSF, Santos VWS, Damasceno EM, Araújo JF, Sousa ALM, Vieira LS. An epidemiological study of caprine arthritis encephalitis virus (CAEV) in breeder goats from Northeastern Brazil. Semin Cienc Agrar. 2019;40(5):1857-66. http://dx.doi. org/10.5433/1679-0359.2019v40n5p1857.

Souza TS, Costa JN, Martinez PM, Lima CCV, Araújo BR, Costa Neto AO, Anunciação AVM, Almeida MGAR, Pinheiro RR. Inquérito soro-epidemiológico de Brucella ovis em rebanhos ovinos no semiárido baiano. Arq Inst Biol. 2012;79(2):277-81. http://dx.doi.org/10.1590/S180816572012000200017.

Suepaul SM, Carrington CV, Campbell M, Borde G, Adesiyun AA. Seroepidemiology of leptospirosis in livestock in Trinidad. Trop Anim Health Prod. 2011;43(2):367-75. http:// dx.doi.org/10.1007/s11250-010-9698-8. PMid:20953838.

Suwancharoen D, Chaisakdanugull Y, Thanapongtharm W, Yoshida S. Serological survey of leptospirosis in livestock in Thailand. Epidemiol Infect. 2013;141(11):2269-77. http:// dx.doi.org/10.1017/S0950268812002981. PMid:23308397.

Torres-Velez F, Havas KA, Spiegel K, Brown C. Transboundary animal diseases as re-emerging threats-Impact on onehealth. Semin Diagn Pathol. 2019;36(3):193-6. http://dx.doi. org/10.1053/j.semdp.2019.04.013. PMid:31053264.

World Organisation for Animal Health. Criteria for the inclusion of diseases, infections and infestations in the OIE list,Terrestrial Animal Health Code [Internet]. Paris: OIE; 2019 [cited 2020 Dec 22]. Available from: https://www.oie. int/fileadmin/Home/eng/Health_standards/tahc/current/ chapitre_criteria_diseases.pdf.

World Organisation for Animal Health. Manual of Diagnostic Tests and Vaccines for Terrestrial Animals [Internet]. Paris: OIE; 2018 [cited 2020 Dec 22]. Available from: https://www. oie.int/standard-setting/terrestrial-manual/.

Financial Support: FAPESB (Fundação de Amparo à Pesquisa do Estado da Bahia) (Grant No. PPP/FAPESB 0034/2011). 